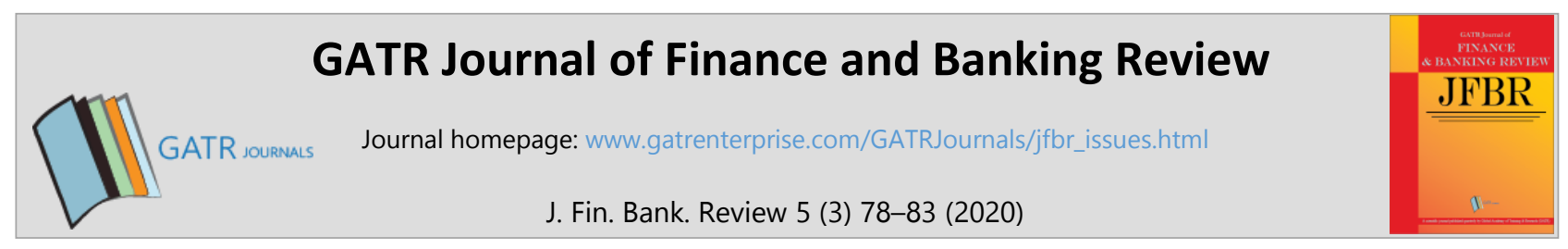

\title{
Cultural Values and Perceived Audit Quality: A Conceptual Framework
}

\author{
Samirah Dunakhir ${ }^{1 *}$, Mukhammad Idrus² \\ ${ }^{1,2}$ Faculty of Economic, Universitas Negeri Makassar, Indonesia
}

\begin{abstract}
Objective - This paper aims to propose a framework for cultural values and perceived audit quality

Methodology/Technique - The methodology used in this study is the content analysis of the published papers in relation to cultural values and perceived audit quality

Findings - There is a strong relationship between cultural values and accounting values in the judgement process of auditing and they determine the quality of audit.
\end{abstract}

Novelty - There is not much information published in the area of the roles of cultural values and perceived audit quality. Therefore, this paper offers a conceptual framework on cultural values and perceived audit quality.

Type of Paper: Review

Keywords: Culture; Cultural Values; Perception; Audit Quality

Reference to this paper should be made as follows: Dunakhir, S; Idrus, M. (2020). Cultural Values and Perceived Audit Quality: A Conceptual Framework, J. Fin. Bank. Review, 5 (3): 78 - 83. https://doi.org/10.35609/jfbr.2020.5.3(2)

JEL Classification: M4, M42.

\section{Introduction}

There is an increasing interest of researching cultural relativism in the field of accounting and auditing. Riahi-Belkaoui (1995) developed a cultural relativism in accounting model based on a cognitive perspective view. He suggests that unique cultural communities "create different cognitions or systems of knowledge for intracultural communications and/or intercultural communications" (p. 53).

Differences in cultures can be seen in terms of the value systems. Geert Hofstede developed a framework of value system culture (Patel, 2004). Hofstede, et al. (2010) concept which contains six factors: (1) individuality versus collectivity; (2) high and low power distance; (3) robust versus weak uncertainty avoidance; (4) masculinity versus femininity; (5) long-standing versus short-range direction; and (6) tolerance versus restraint. The short and long-term direction has pragmatic perspectives, which have both conventional and historical views (Hofstede, et al., 2010). Meanwhile, the sixth dimension (indulgence versus restraint) was developed from the literature on "happiness research" (Hofstede, et al., 2010). These last two aspects are still not widely understood and are also not directly correlated to the topic of this study.

\footnotetext{
* Paper Info: Revised: September 19, 2020

Accepted: December 31, 2020

* Corresponding author: Samirah Dunakhir

E-mail: samirah.dunakhir@unm.ac.id

Affiliation: Faculty of Economic, Universitas Negeri Makassar, Indonesia
} 
Therefore, these dimensions are excluded from the investigation. In addition, the first four taxonomy has been realized intercultural accounting study comprehensively. According to Hofstede (2011), it is a fact that the four factors he proposed are themes applied globally, even though the original data they are based on were taken from the perspectives of transnational workers. Jones (2007) suggests to continue more studies of the application of Hosftede's concept in different geographical settings.

The influence of culture in auditing and accounting issues have been investigated by many researchers. For example, the influence of culture in audit and financial reporting judgments (Chan, et al., 2003; Haniffa \& Cooke, 2002; Lin \& Fraser, 2008), auditor independence (Agacer \& Doupnik, 1991; Patel \& Psaros, 2000; Stevenson, 2002), and ethical perception (Arnold, et al., 2007; Smith \& Hume, 2005). However, cultural research on particular aspects of audit quality perceptions has not been analysed closely, even though cultural values contribute to a strong influence on perceptions of the quality of audit. Recognizing culture impact on perceived audit quality can make regulators aware of market expectation. As a result, they will be able to improve actual audit quality through the legal and accounting standards they set.

The aim of this paper is to explore the conceptual framework of cultural values and audit quality in accounting. The following section is the literature review, research methodology, result and discussion, and managerial implication and conclusion.

\section{Literature Review}

Recent research in cross-cultural studies in auditing considers the influence of identity background in the implementation of Global Standards on Auditing. Cowperthwaite (2010) was concerned that several nations encounter problems in the realization of the standard. The cultural dimension may not be the same as it is applied due to distinctive national cultures. Cultural values believed to be relevant in this situation are control, insecurity anticipation, and individuality/collectivism (Cowperthwaite, 2010). For instance, cultures least control distance will differ in their approach to ISA requirements. In cultures with low power distance, the encouragement for practices to convert to ISA audits may come from local leaders in the profession and from bottom-up change. However, in high power distance cultures, the urge for change will come from those in authority.

Other studies in cross-cultural auditing investigate the influence of culture on the views of auditor's objectivity and ethical practices. Perceptions of auditor judgement can differ due to differences in culture. Patel (2000) found significant differences among their participants from developed countries in relation to their perceptions of an external auditor's independence. Stevenson (2002) also states that there is a significant difference on the positions of auditor independence in Italy, France and UK. Kosmala (2007) investigated the cultural influence on the construction auditor independence in Poland and the Czech Republic. The study was motivated by the growing interests for harmonization of governance cooperate system and accountability but did not consider the particularities of culture. The results showed that the interpretation of independence is perceived differently in those countries.

Moreover, many cross-cultural studies in auditing have sought to find the connection of culture and the view of ethical and unethical behaviour. This is because "culture plays an important role in defining ethical standards" (Cohen, et al., 1992, p. 690). Table 1 shows how cultural dimensions can impact on the acceptability and implementation of the global conduct codes relating to integrity, objectivity, confidentially, and professional behaviour of auditors. For instance, subordinates in strong control power distance countries tend to be more loyal to their employers despite their employees perform unethical audit behaviour.

Cohen, et al. (1992) proposed a concept for assessing international codes of conducts that contains honesty, independency, confidentiality, and professional attitudes. This framework was supported by Armstrong (1996). His study identified that there is a correlation of the two important Hofstede's cultural components: uncertainty avoidance, individuality and ethical views. Teoh, et al. (1999) investigated the perceptions of unethical practices between collectivistic Indonesian students and individualistic Australian students. They found perceptual differences between the two nations: "Indonesian students tended to perceive 
a greater amount of gain if this gain impacts more on close or moderately close in-groups" (Teoh, et al., 1999, p. 150).

Similarly, the other study showed the mean ethical perceptive p scores obtained in Australia and China are different. This can be explained by Hofstede's cultural dimensions. The Chinese mainland is categorised as long-standing orientation, low insecurity avoidance, limited individuality, and strong control distance. Australia, in contrast, is classified as of strong uncertainty avoidance, high individualism, small power distance and short-term orientation (Tsui and Windsor, 2001).

Some other studies have provided evidence that Hofstede's cultural values can influence perceptions of appropriate ethical actions by auditors. Arnold, et al. (2007), for example, examined the impact of a nation cultural values on the application of conduct code in European countries. The study found that there is a distinctive mode of application of ethical attitudes in relation to the realization of codes of conduct. This is due to the differences of participants' cultural backgrounds. The evidence indicated that these nations' cultural dissimilarities are connected with Hofstede's dimension of cultures. Roxas and Stoneback (1997) also found that various cultures perceive ethical dilemmas differently. Their study examined the impact of cultural components on the ethics of decision-making processes (problem, action, and impact). They showed that culture affects every element of the ethical process of decision-making. In addition, Dunakhir (2016) found that characteristics of the professionals, which were shaped by their environment, have influenced their ability to interpret and apply the auditing regulations and standards.

The other study investigated the influence of cultural values on the choice of auditors (Hope, et al., 2008); auditors' abilities to perform analytical procedures (Hughes, et al., 2009); and auditors' judgment (Arnold, et al., 2009; Nasution \& Östermark, 2012). These studies provide strong support for the influence of cultural components on the profession of auditors.

\section{Methodology}

The method used in this study is content analysis. Content analysis is a study of systematic symbolic content for analysing books, newspapers, websites, and ads. Content analysis enables researchers to analyze a large amount of the research focus, as well as identify characteristics such as concepts, words, sentences or themes. Content analysis can be either relational analysis or conceptual papers or published papers. The published paper to analyse in this article is in table 1 below:

Table 1: Relevant published papers for content analysis

\begin{tabular}{|c|c|}
\hline No & Published papers \\
\hline 1 & $\begin{array}{r}\text { Duff, A. (2004). Auditqual: Dimensions of Audit Quality: The Institute of Chartered Accountants of } \\
\text { Scotland, CA House, Edinburgh EH12 5BH. }\end{array}$ \\
\hline 2 & $\begin{array}{r}\text { Duff, A. (2009). Measuring audit quality in an era of change: An empirical investigation of UK audit } \\
\text { market stakeholders in 2002 and 2005. Managerial Auditing Journal, 24(5), 400-422. }\end{array}$ \\
\hline 3 & $\begin{array}{r}\text { Laroche, M., Ueltschy, L. C., Abe, S., Cleveland, M., \& Yannopoulos, P. P. (2004). Service quality } \\
\text { perceptions and customer satisfaction: Evaluating the role of culture. Journal of International Marketing, } \\
12(3), 58-85 .\end{array}$ \\
\hline 4 & $\begin{array}{r}\text { Hofstede, G., Hofstede, G. J., \& Minkov, M. (2010). Cultures and Organizations: Software of the Mind: } \\
\text { Intercultural Cooperation and its Importance for Survival (3rd ed.). New York: McGraw-Hill. }\end{array}$ \\
\hline 5 & $\begin{array}{r}\text { Hofstede, G. (2011). Dimensionalizing cultures: The Hofstede model in context. Online Readings in } \\
\text { Psychology and Culture, 2(1), 8-17. }\end{array}$ \\
\hline 7 & $\begin{array}{c}\text { Tinker, T., \& Gray, R. (2003). Beyond a critique of pure reason: From policy to politics to praxis in } \\
\text { environmental and social research. Accounting, Auditing \& Accountability Journal, 16(5), 727-761. }\end{array}$ \\
\hline
\end{tabular}

The reason of choosing these six papers is that these are the most relevant papers in relation to cultural values and perceived audit values that appear mostly in the google scholars. 


\section{Result and Discussion}

From the analysis, the authors draw a conceptual framework for cultural values and audit quality perceptions.

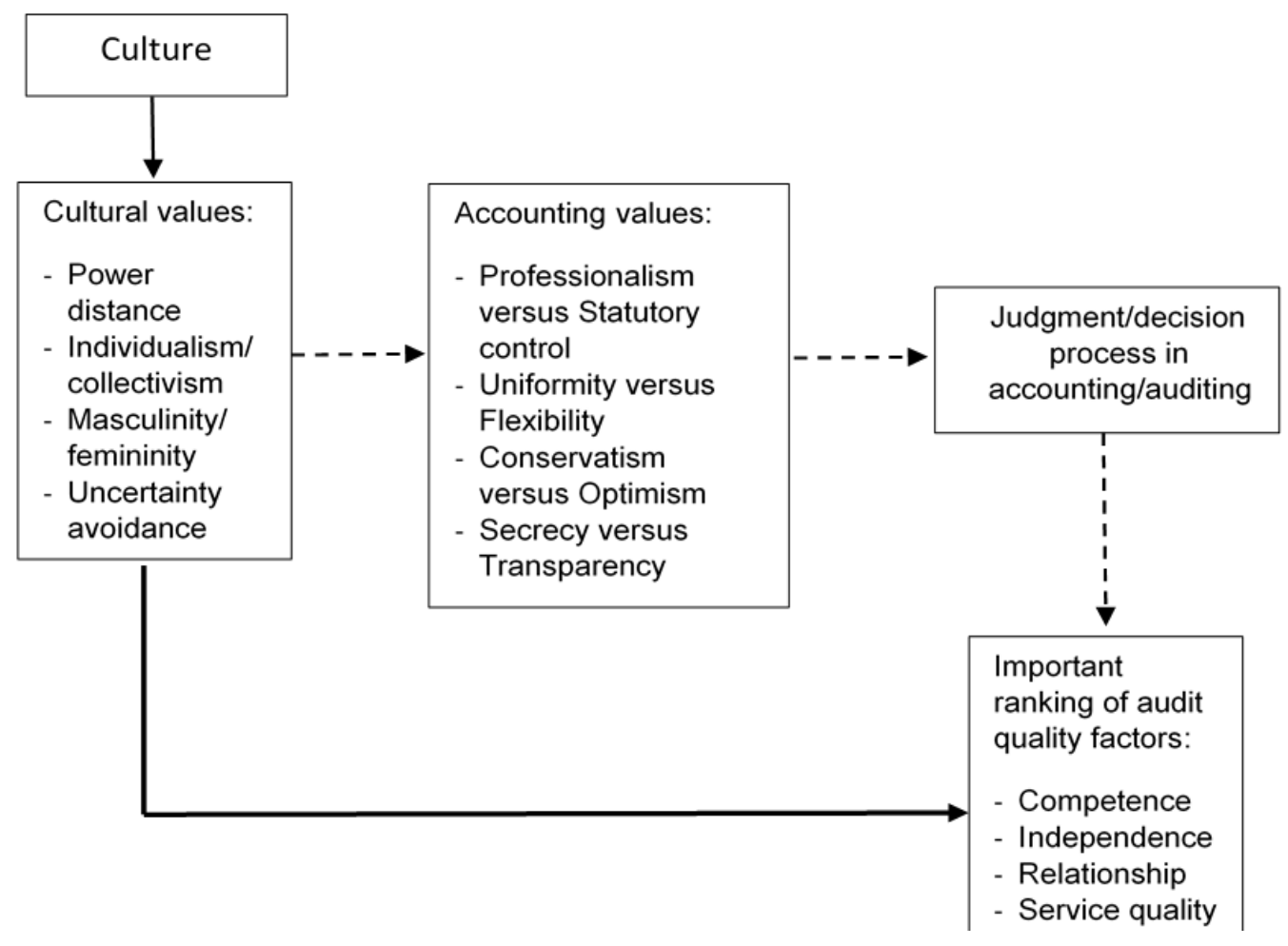

Figure 1: a conceptual framework for cultural values and audit quality perceptions

Culture, (Figure 1 above), according to Hofstede (2010), can be viewed as mental software or mental programming - that is, as collective frame for a person deriving from the social environment in which (s)he grew up and collected life experiences. Because they are acquired from the social environment, mental programs vary according to where they are acquired. Therefore, different human groups will have different views on the same things. Cultural values vary along four elements: high/low control distance; individualist/collectivist; masculinist/feminisms; and robust/fragile indecision avoidance ( Hofstede, 2011).

Academic research on audit quality has broadened attention to include market perceptions of that quality. From his comprehensive study, Duff (2004) developed the AUDITQUAL model. Duff's model recognised that "audit quality is made up of both service quality issues and the need to deliver technical quality" (Duff, 2004, p. xi). The model derived from the research on audit with the participants in the UK. It contains the importance of audit quality factors which may not be the same as in another society. Different countries provided different quality of audit views. For instance, the US participants perceived that "the audit team and firm experience with the client" was very important in determining audit quality. However, participants in Denmark perceived that "moral and ethical aspects" were the important components in the audit quality factors. It is due to the "perceptions are filtered through the lens of culture" (Laroche, et al., 2004, p. 62).

Based on Hofstede's definitions of culture, this study assumes that the relative importance of each AUDITQUAL factor will vary across groups of people from several backgrounds of different cultures. Hence, the importance of each AUDITQUAL factor in a country like Indonesia will vary from the UK's AUDITQUAL factors.

The earlier work in the field of accounting model that is proposed by Tinker and Gray, (2003) that explains four accounting values including professional and statutory control; homogeneity versus flexibility; 
conservative versus optimistic views; and secrecy versus transparency. As a result, these accounting values influence judgment/decision process in accounting/auditing (Riahi-Belkaoui, 1995). Following Gray and Riahi-Belkaoui's work, the thesis extends this connection to auditing by applying Duff's (2009) AUDITQUAL model and Hofstede (2010). Therefore, the conceptual framework depicts the relation between culture and perceptions of audit quality. The conceptual framework showed in Figure 1 features audit quality factors. These factors were created according to the views of audit market participants, which are influenced by cultural values components. The importance of audit quality factors, in turn, reflects the cultural background of the market targeted. Therefore, the complete set of propositions relating to Hofstede's cultural dimensions to the AUDITQUAL factors.

The conceptual framework presented considers the values of culture in the control distance, individualist/collectivists, feminisms/masculinists, and uncertainty avoidance may impact the relative importance of audit quality factors (competence, independence, relationship, and service quality) in different nations. This is based on the concept of cultural relativism: human groups think, feel, and act differently. Such differences are manifest in auditors' identities. Values are at the core of culture and direct people to act in certain ways. Therefore, human groups have different perceptions of things based on their cultural value perspective.

\section{Conclusion}

This paper offers a framework of cultural values and audit quality perception. It enhances knowledge of the impact of national values of cultures on the perceptions of quality audit attributes. Given ongoing globalisation and the fact that audits are performed by auditors from a multitude of nations, it is important that auditing research captures perspectives from different cultural backgrounds. Auditors may comply with the same set of international standards but interpret and apply them differently. Through that conceptual framework, it was suggested that the views of the importance on the audit quality factors were influenced by cultural values of power distance, individualists/collectivists, masculinist/femininity, and uncertainty avoidance. It was expected that due to individuals' culture of large power distance, collectivism and feminism, they would rate the importance of audit quality factors differently when compared between countries. Key findings derived from the qualitative study confirmed that the differences in opinions of the significance of audit quality factors in one country could be due to differences in cultural characteristics. For further consideration, it is necessary to develop a questionnaire instrument or a list of interview questions to assess each component of a conceptual model on cultural values and perceived audit for future investigations.

\section{References}

Agacer, G. M., \& Doupnik, T. S. (1991). Perceptions of auditor independence: A cross-cultural study. International Journal of Accounting, 26(3), 220-237.

Armstrong, R. W. (1996). The relationship between culture and perception of ethical problems in international marketing. Journal of Business Ethics, 15(11), 1199-1208. doi: 10.1007/bf00412818

Arnold, D. F., Bernardi, R. A., \& Neidermeyer, P. E. (2009). Do European auditors' decisions reflect harmony? The impact of country and culture. International Journal of Disclosure and Governance, 6(1), 58-68.

Arnold, D. F., Bernardi, R. A., Neidermeyer, P. E., \& Schmee, J. (2007). The effect of country and culture on perceptions of appropriate ethical actions prescribed by codes of conduct: A Western European perspective among accountants. Journal of Business Ethics, 70(4), 327-340. https://doi.org/10.1007/s10551-006-9113-6

Chan, K. H., Lin, K. Z., \& Mo, P. L. L. (2003). An empirical study on the impact of culture on audit-detected accounting errors. Auditing: A Journal of Practice \& Theory, 22(2), 281-295. https://doi.org/10.2308/aud.2003.22.2.281 Cohen, J. R., Pant, L. W., \& Sharp, D. J. (1992). Cultural and socioeconomic constraints on international codes of ethics: Lessons from accounting. Journal of Business Ethics, 11(9), 687-700. https://doi.org/10.1007/BF01686349 
Cowperthwaite, P. (2010). Culture matters: How our culture affects the audit. Accounting Perspectives, 9(3), $175-215$. https://doi.org/10.1111/j.1911-3838.2010.00010.x

Duff, A. (2004). Auditqual: Dimensions of audit quality. Edinburgh: Institute of Chartered Accountants of Scotland.

Duff, A. (2009). Measuring audit quality in an era of change. Managerial Auditing Journal. https://doi.org/10.1108/02686900910956784

Dunakhir, S. (2016). Factors associated with audit quality: Evidence from an emerging market. Asia Pacific Journal of Advanced Business and Social Studies, 2(2), 523-533.

Haniffa, R. M., \& Cooke, T. E. (2002). Culture, corporate governance and disclosure in Malaysian corporations. Abacus, 38(3), 317-349. doi: 10.1111/1467-6281.00112

Hofstede, G., Hofstede, G. J., \& Minkov, M. (2010). Cultures and Organizations, Software of the mind. Intercultural Cooperation and Its Importance for survival.

Hofstede, G. (2011). Dimensionalizing cultures: The Hofstede model in context. Online readings in psychology and culture, 2(1), 2307-0919.

Hope, O. K., Kang, T., Thomas, W., \& Yoo, Y. K. (2008). Culture and auditor choice: A test of the secrecy hypothesis. Journal of Accounting and Public Policy, 27(5), 357-373. https://doi.org/10.1016/j.jaccpubpol.2008.07.003

Hughes, S. B., Sander, J. F., Higgs, S. D., \& Cullinan, C. P. (2009). The impact of cultural environment on entry-level auditors' abilities to perform analytical procedures. Journal of International Accounting, Auditing and Taxation, 18(1), 29-43. https://doi.org/10.1016/j.intaccaudtax.2008.12.004

Jones, M. L. (2007). Hofstede-culturally questionable?

Kosmala, K. (2007). (Un) realised independence in the CEE region: Insights from interpretive cultural theory. Critical Perspectives on Accounting, 18(3), 315-342.doi: http://dx.doi.org/10.1016/j.cpa.2005.11.013

Laroche, M., Ueltschy, L. C., Abe, S., Cleveland, M., \& Yannopoulos, P. P. (2004). Service quality perceptions and customer satisfaction: evaluating the role of culture. Journal of international marketing, 12(3), 58-85. https://doi.org/10.1509/jimk.12.3.58.38100

Lin, K. Z., \& Fraser, I. A. (2008). Auditors' ability to resist client pressure and culture: Perceptions in China and the United Kingdom. Journal of International Financial Management \& Accounting, 19(2), 161-183. https://doi.org/10.1111/j.1467-646X.2008.01020.x

Nasution, D., \& Östermark, R. (2012). The Impact of Social Pressures, locus of control, and professional commitment on Auditors' Judgment. Asian Review of Accounting. https://doi.org/10.1108/13217341211242204

Patel, C., \& Psaros, J. (2000). Perceptions of External Auditors'independence: Some Cross-Cultural Evidence. The British Accounting Review, 32(3), 311-338. https://doi.org/10.1006/bare.2000.0138

Riahi-Belkaoui, A. (1995). The cultural shaping of accounting. Greenwood Publishing Group.

Smith, A., \& Hume, E. C. (2005). Linking culture and ethics: A comparison of accountants' ethical belief systems in the individualism/collectivism and power distance contexts. Journal of Business Ethics, 62(3), 209-220. doi: 10.1007/s10551-005-4773-1

Stevenson, J. E. (2002). Auditor independence: A comparative descriptive study of the UK, France and Italy. International Journal of Auditing, 6(2), 155-182. doi:10.1111/j.1099-1123.2002.tb00011.x

Tinker, T., \& Gray, R. (2003). Beyond a critique of pure reason: from policy to politics to praxis in environmental and social research. Accounting, Auditing \& Accountability Journal. https://doi.org/10.1108/09513570310505952

Teoh, H. Y., Serang, D. P., \& Lim, C. C. (1999). Individualism-collectivism cultural differences affecting perceptions of unethical practices: Some evidence from Australian and Indonesian accounting students. Teaching Business Ethics, 3(2), 137-153. doi: 10.1023/a:1009832018849

Tsui, J., \& Windsor, C. (2001). Some cross-cultural evidence on ethical reasoning. Journal of Business Ethics, 31(2), 143-150.doi: 10.1023/a:1010727320265 